\title{
THE ROLE OF TRADE UNION IN ENSURING PRODUCTIVITY IN AN ORGANIZATION: A CASE OF GENERAL AGRICULTURAL WORKERS UNION (GAWU) IN GHANA
}

\author{
Emmanuel Asiedu-Darko ${ }^{1 凶}$ (D), Saffiatu Quaye $2 \square$ (D), Rita Acheampong ${ }^{3} \square$ \\ ${ }^{1}$ CSIR-Plant Genetic Resources Research Institute, Ghana \\ ${ }^{2}$ Council for Scientific and Industrial Research-Head Office, Ghana. \\ ${ }^{3}$ University College of Agriculture and Environmental Studies, Ghana.
}

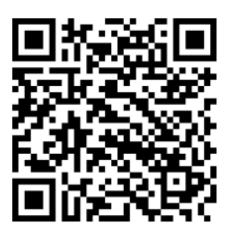

Received 5 December 2021

Accepted 16 December 2021

Published 31 January 2022

\section{Corresponding Author}

Emmanuel Asiedu-Darko, easiedudarko@yahoo.com

DOI

10.29121/granthaalayah.v10.i1.2022 .4452

Funding: This research received no specific grant from any funding agency in the public, commercial, or not-for-profit sectors.

Copyright: (C) 2022 The Author(s). This is an open access article distributed under the terms of the Creative Commons Attribution License, which permits unrestricted use, distribution, and reproduction in any medium, provided the original author and source are credited.

\section{ABSTRACT}

This work was carried out to assess the role of trade unions in ensuring productivity in an organization The General Agricultural Workers Union (GAWU) of Trade Union Congress in Ghana was considered as the target population of which one hundred members were interviewed. Questionnaires were used to solicit views from unionized employees selected for the study. Five union leaders identified under GAWU were also interviewed through face to face. The research assumed content analysis to evaluate how the union activities involving increasing co-operation and wellbeing among workers, Work for the progress employees, ensure punctuality to work and facilitate job security and reduce pressure. The result revealed that members were not enthused about the union's role in ensuring punctuality to work, working for progress of employees and facilitating job security and reducing pressure. However, members applauded the Union efforts in ensuring increased communication between the employer and the employees. The study suggested that there is a need for the Union to ensure that those workers play their roles as expected of them to ensure productivity in the organization. Workers should be motivated, that putting organizational interest first rather than personal interest is crucial to the sustainability of every organization.

Keywords: GAWU, Trade Union, Organization, Productivity, Employer

\section{INTRODUCTION}

The existence of unions plays a significant role in the structure of any organization and for the management of the organization's human resources for the achievement of organizational goals. It is important for the Union and Management of every organization to agree on some basic written agreement to ensure fruitful working relationship. To buttress this point Visser 2020 opined that a labor relations officer's job in a unionized firm will be obviously different from that same job in a non-unionized firm.

Baskin (2001) defines trade union as association of individual workers that represent themselves as a unit in negotiating with their employer. The writer is of the view that, trade unions are formed primarily to advance and protect the interest of their members. This assertion of trade union raises many questions as to the existence of trade unions and their benefit to the organization as a whole.

Meardi (2000) sees trade union as an organization of workers who have come together to achieve common goals such as protecting the integrity of its 
trade, improving safety standards, achieving higher pay and benefits such as health care and retirement, increasing the number of employees an employer assign to complete the work, and better working conditions. Trade Union can be described as continuous association of wage earners for the purpose of sustaining and enhancing conditions in the workplace Hyman (2021). Basically, a trade union fights for better working conditions and remuneration for its members Taylor and Bain (2001). They advocate for sound relations between employers and employees through the promotion and protection of freedom of association, collective bargaining agreements and dispute resolution Gallin (2001). More specifically, trade unions negotiate for wages, work rules, complaint procedures, rules governing hiring, firing and promotion of workers, benefits, workplace safety and policies Deakin and Morris (2012).

If trade unions exist to advance and protect the interest of their members, then it is fair to question their commitment and contribution to the organization. As argued and advanced by Henry Fayol the organizational interest is supposed to override the individual interest in one of his fourteen principles of management, then the role of trade unions should be situated in the proper context.

However, Checchi and Lucifora (2002) held the view that the existence of trade unions is to have a positive impact on productivity since making employees feel part of the organization through the formation of associations serve as a means of intrinsic motivation for them to put their best.

It is against this background that this study was embarked to investigate the role of trade unions in ensuring productivity in an organization.

\section{METHODOLOGY}

Primary data were collected through, distributing of questionnaires and interviews. Mixed approach method i.e., both quantitative and qualitative methods were adopted to achieve the research objectives. Both data set described the perceptions of respondents about the labour union effectiveness in its major practice in enhancing the employees' performance using content analysis. Likert five-point Scales were adopted in questionnaire to obtain and measure the performance of employees on the selected practices of labour union i.e., '1' For Strongly Dis-Agree,'2' Disagree,'3' Neutral, '4 'For Agree and ‘5' For Strongly Agree. Since the data which were acquired using likert scales were ordinal data types, mode of frequencies and percentage were used to measure the central tendency of the data in the data set and to describe about the majority of or the average levels of agreement of the respondents about the subject matter respectively.

\section{RESULTS AND DISCUSSIONS}

Variables assessed to identify demographic characteristics of the respondents included gender, age educational level and years of employment of the respondents. The results showed that $62 \%$ of the respondents that data was collected from were males whereas $38 \%$ were females. Furthermore, majority of the respondents were highly educated, $71 \%$ having attained tertiary education, $20 \%$ secondary and $10 \%$ primary education, respectively.

From the total percentage based on age, $1.92 \%$ respondents were from the ages of $18-25$ years, $28.85 \%$ respondents were from the ages of $26-35$ years, $30.77 \%$ representing the ages of 36-45 years. Also, $42-50$ years of age respondents had a percentage of $1.92 \%, 23.08 \%$ represented the ages of $46-55$ years, whilst $13.46 \%$ represented respondents from the ages of 56-60 years. 
Based on the year of employment, $25.00 \%$ from the total percentage were respondents who fell in the range from 1-10 years of being employed, 53.85\% were in the range from 11-20 years, and $7.69 \%$ were also in the range from $21-30$ years, whilst $13.47 \%$ fell in the range from 31 and above years of being employed.

\begin{tabular}{|cc}
\hline Table 1: Demographic characteristics of the respondents \\
\hline Gender & \% Of Total \\
\hline Female & $38.46 \%$ \\
Male & $61.54 \%$ \\
\hline Educational Level & \\
\hline Basic & $9.80 \%$ \\
\hline Secondary & $19.61 \%$ \\
\hline Tertiary & $70.59 \%$ \\
\hline Years of Employment & \\
\hline $10-J a n$ & $25.00 \%$ \\
\hline $20-$ Nov & $53.85 \%$ \\
$21-30$ & $7.69 \%$ \\
\hline 31 and above & $13.47 \%$ \\
Age & \\
\hline $18-25$ & $1.92 \%$ \\
\hline $26-35$ & $28.85 \%$ \\
$36-45$ & $30.77 \%$ \\
$42-50$ & $1.92 \%$ \\
$46-55$ & $23.08 \%$ \\
$56-60$ & $13.46 \%$ \\
\hline
\end{tabular}

\begin{tabular}{|c|c|c|c|c|c|}
\hline & & & $\%$ & & \\
\hline $\begin{array}{c}\text { Activities of Trade } \\
\text { Union }\end{array}$ & Strongly disagree & Disagree & Neutral & Agree & Strongly agree \\
\hline $\begin{array}{l}\text { Facilitates job security } \\
\text { and reduce pressure }\end{array}$ & 7.69 & 36.54 & 15.38 & 36.54 & 3.85 \\
\hline $\begin{array}{c}\text { Increased communication } \\
\text { between employer and } \\
\text { employee }\end{array}$ & 1.92 & 19.23 & 30.77 & 42.31 & 5.77 \\
\hline $\begin{array}{l}\text { Facilitates the acquisition } \\
\text { of required skills for the } \\
\text { job }\end{array}$ & 15.38 & 38.46 & 25 & 19.23 & 1.92 \\
\hline $\begin{array}{l}\text { Ensure punctuality to } \\
\text { work }\end{array}$ & 17.31 & 44.23 & 21.15 & 9.62 & 7.69 \\
\hline $\begin{array}{l}\text { Facilitates the ironing out } \\
\text { of the workers grievances }\end{array}$ & 3.85 & 9.62 & 5.77 & 65.38 & 15.38 \\
\hline
\end{tabular}

The primary focus of the study was to explore the knowledge of employees on the trade union activities. The results indicated that $80.76 \%$ of the respondents were fully aware of the activities of Trade Union. This finding is in consistent with the study conducted Bakolor and Antwi (2020) which indicated that majority of the employees at the Food and Drugs Board were familiar with the activities of the Trade Union. Abedi et al. (2011) also affirmed this assertion in a study conducted at MTN on the activities of trade union.

From the result, it was observed that $36.54 \%$ respondents disagreed and at the same time agreed with $3.85 \%$ respondents strongly agreeing. $7.69 \%$ respondents 
strongly disagreed whilst $15 \%$ respondents were neutral to the activities of trade union to facilitate job security and reduce pressure. Only $40.39 \%$ agreed on the facilitation on job security by trade unions for members which is an indication that the confidence of members in trade unions is low. Boamah (2014) revealed that members doubted the ability of trade unions to protect them only $32 \%$ strongly agreed on the ability of trade unions to protect its members. This scenario is discouraging since according to Hafford and Koops (2009) the primary function of trade union is to protect its members.

It was also observed that $42 \%$ respondents agreed to increased communication between employer and employee whilst $30.77 \%$ respondents were neutral. $19.23 \%$ respondents disagreed with $1.92 \%$ respondents strongly disagreeing, leaving $5.77 \%$ respondents strongly agreeing.

From the opinions on activities of trade union to facilitate the acquisition of required skills for the job, $38.46 \%$ respondents disagreed whilst $15.38 \%$ respondents strongly disagreed. Neutral respondents were 25\%, then $19.23 \%$ respondents agreed whilst $1.92 \%$ respondents strongly agreed.

Having the required skills for the job is crucial to increasing productivity in every organization. The finding of the study revealed that majority of the respondents doubted trade union ability to ensure the acquisition the right skills for its members.

With ensuring punctuality to work, $44.23 \%$ respondents disagreed, $21.15 \%$ respondents were neutral and $17.31 \%$ respondents strongly disagreed. $9.62 \%$ respondents agreed whilst $7.69 \%$ respondents strongly agreed.

In terms of ensuring punctuality of its members to work, the results indicated the trade union has failed in this regard. This consistence with the findings of Compa (2004) which indicated that Employers often allege that labor unions, only talk about workers' rights and ignore their obligations. They believe that unions are largely responsible for low productivity and poor performance in many organizations.

From facilitating the ironing out of the workers grievances result, it was observed that $65.38 \%$ respondents agreed with $15.38 \%$ respondents strongly agreeing. Respondents disagreeing were $9.62 \%$ whist $3.85 \%$ respondents strongly disagreed leaving $5.77 \%$ respondents being neutral.

According to Guthrie (2000), conflicts are strong catalyst to job dissatisfaction which in turn causes productivity to decline in any given organization. This implies that for the promotion of the organizational performance conflicts should be kept minimal in any organization. A study conducted by Floyd and Lane (2000) averred that trade unions over the years have contributed to ironing out workers grievances in an organization. The findings of the study attested to this fact since respondents scored trade unions high in terms ironing out of workers grievances.

In assessing union activities and its influence on performance of unionized firms in Ghana, Dwomoh and Kwarteng (2015) concluded that it will be prudent for further research to be carried out focusing on how union activities influence employee's performance which will have positive effect on organizational performance.

The study also explored the relationships between gender, educational level on increasing co-operation and wellbeing among workers, works for the progress of employees and ensuring punctuality to work. 


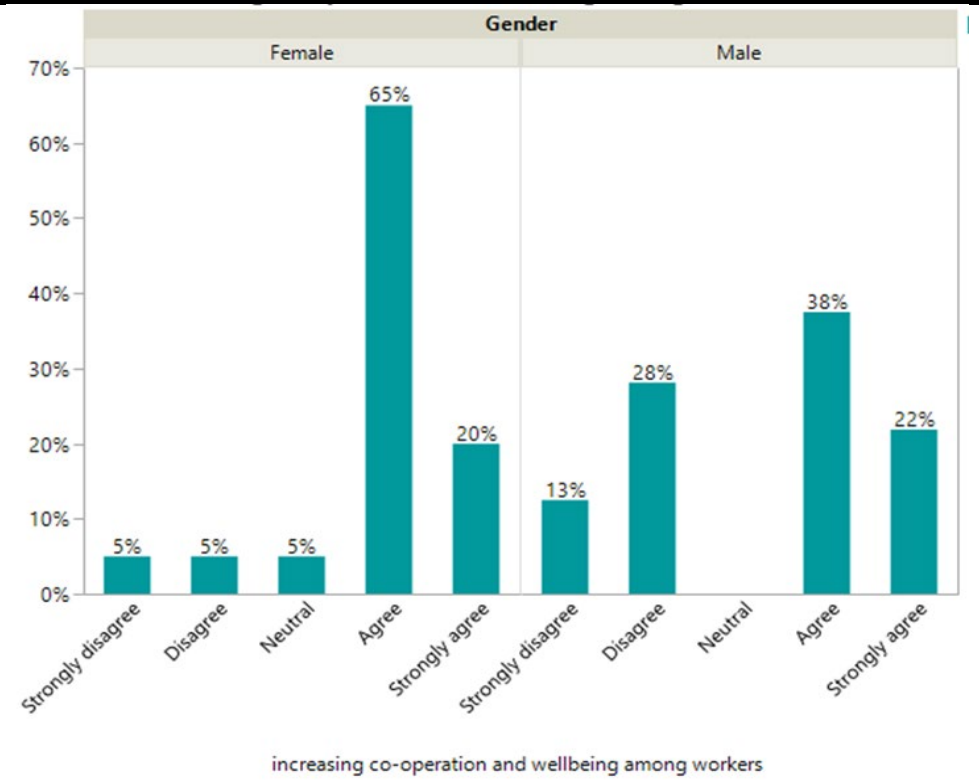

From the graph it was observed that $65 \%$ females agreed to increasing cooperation and wellbeing among workers whilst 38\% males agreed. $20 \%$ females strongly agreed and 22\% males strongly agreed. 5\% females strongly disagreed, disagreed and were neutral respectively whilst $13 \%$ males strongly agreed, $28 \%$ disagreed and $0 \%$ were neutral.

The results from the above graph indicated that majority of the female respondents gave a thump up to Trade Unions in terms of increasing co-operation and wellbeing among workers. In terms of education in relation to increasing cooperation and wellbeing among workers majority of the respondents across the different level's education were of the view that Trade Unions have done well in respect of increasing co-operation and wellbeing among workers as indicated on the graph below.

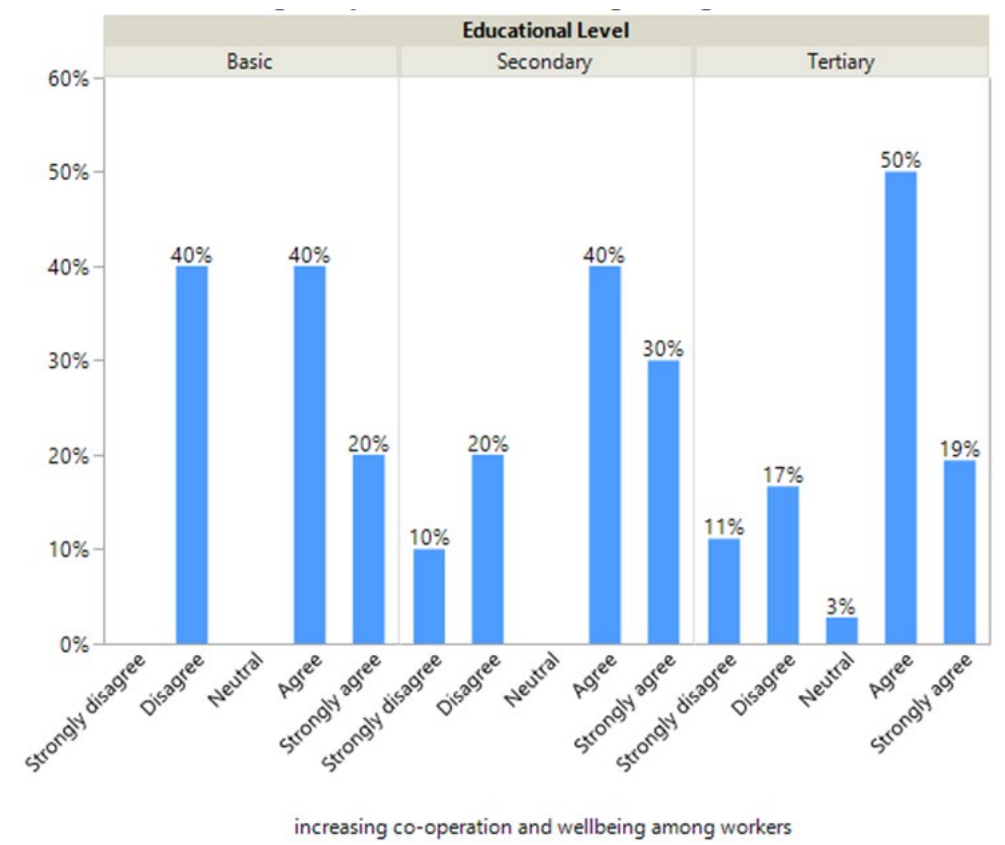

Based on the educational level from the graph, it was observed that $40 \%$ respondents from the basic level agreed respectively whilst $40 \%$ from the 
secondary level agreed on increasing cooperation and wellbeing among workers. $50 \%$ from the tertiary level also agreed, $20 \%$ from the basic level strongly agreed and then 30\% from the secondary level strongly agreed whilst 19\% respondents from the tertiary level also strongly agreed.

$0 \%$ respondents from the basic level strongly disagreed, $10 \%$ from the secondary level strongly disagreed whilst $11 \%$ from the tertiary level also strongly disagreed to increasing cooperation and wellbeing among workers. Again, 0\% respondents from the basic level were neutral as well as from the secondary level whilst 3\% from the tertiary level were neutral.

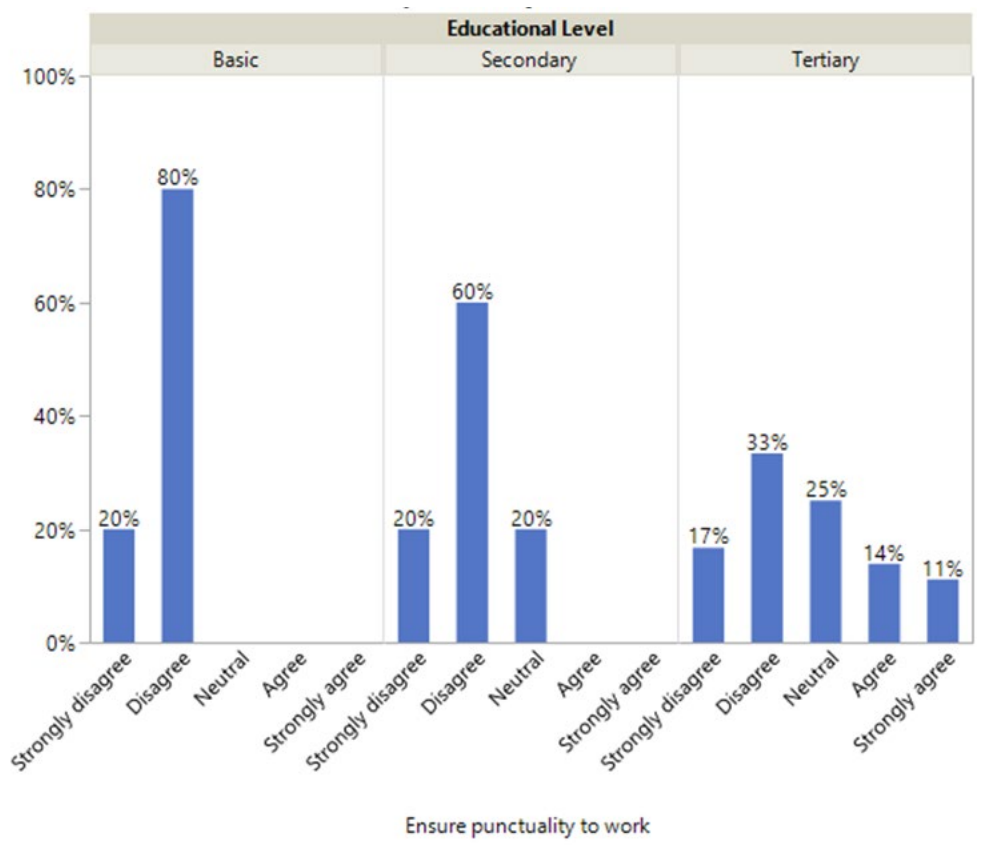

Considering the educational level responses, from the result $80 \%$ basic level respondents, $60 \%$ secondary level respondents, and 33\% tertiary level respondents disagreed to ensuring punctuality to work. $20 \%$ from the basic level strongly disagreed whilst $20 \%$ from the secondary level strongly disagreed and at the same time were neutral. $0 \%$ from the basic level agreed, strongly agreed and were neutral respectively.

Again, $0 \%$ respondents from the secondary level agreed and strongly agreed to ensuring punctuality to work. $17 \%$ from the tertiary level strongly disagreed, $14 \%$ agreed, $11 \%$ strongly disagreed whilst $25 \%$ being neutral.

Trade Unions performed abysmally according to the responses elicited from different level of education of the respondent. It does appear that trade Unions priority is fighting for the welfare of its members neglecting the interest of the organization as depicted clearly on the graph above.

The scenario of Trade Unions not equal to the task of ensuring punctuality at work repeated itself as both male and female respondents shared similar position as indicated on the graph below. 


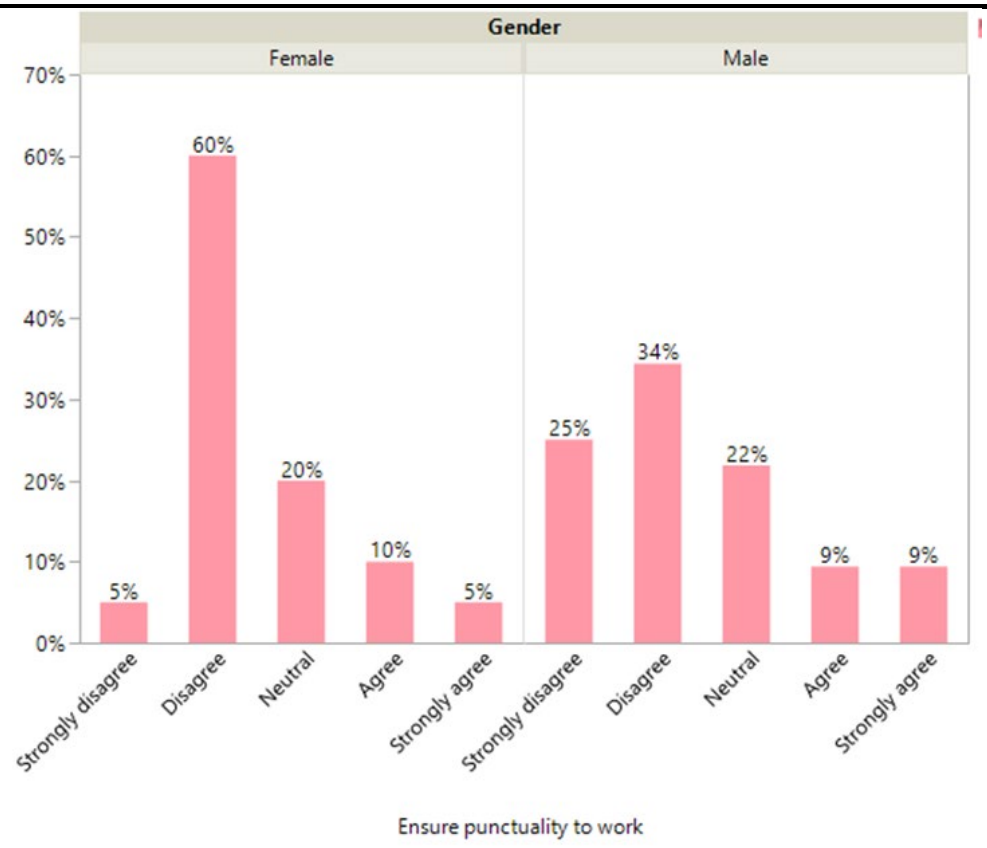

From observation on ensuring punctuality to work, 60\% females disagreed whilst $34 \%$ males disagreed. $20 \%$ females were neutral as well as $22 \%$ males also being neutral, $10 \%$ females strongly disagreed. $5 \%$ females strongly disagreed and also strongly agreed to ensuring punctuality to work. $25 \%$ females strongly disagreed, $9 \%$ males agreed and at the same time strongly disagreed to this activity.

\section{CONCLUSION}

Judging from the findings of the study, the role of Trade Union in ensuring productivity has not been impressive per the findings of the study. The sustainability of the organization depends on the effective and efficient role of Trade Union which seeks to expand the frontiers of the organizations and secure the employment of its members.

It is therefore prudent for Trade Unions to live up to expectation to avoid unnecessary industrial disputes and layoffs.

\section{REFERENCES}

Abedi, B. Immurana, N. Andrews, C. Owusu D. P. Tsinowope, J. K. (2011). The impact of Tade Unions on employees in the Private Sector ; A case Study of MTN Ghana, Kumasi Nhyiaeso Branch, Christian Service University College, Ghana 2011.

Bakolor, S. A. and Antwi D. E. (2020). The effect of trade Union activities on employee-performance ; The case of Ghana Ghana's Food and Drugs Authority.

Baskin J (2001). 'Unions at the Crossroads: Can they make the transition? , South African Labour Bulletin, Vol. 20.

Boamah R, (2014). The effect of Motivation on employees performance empirical evidence from Brong Ahafo Education Directorate. Department of Managerial Science, School of Business Kwame Nkrumah University of Science and Technology, Kumasi. 
Checchi, D and C Lucifora (2002). 'Unions and Labour Market Institutions in Europe, Economic Policy,Vol. 35. Retrieved from https://doi.org/10.1111/14680327.00092

Compa L. A. (2004). Unfair advantage: Workers freedom of association in the United States under international human rights standards. Cornel University Press.

Deakin S. and Morris G. S. (2012). Labour Law. Hart Publishing Ltd, Oxford.

Dwomoh G. and Kwarteng K. (2015). Assessing union activities and its influence on performance of unionized firms in Ghana. Retrieved from https://doi.org/10.12966/ojibm.08.02.2014

Floyd, S. W., and Lane P. J. (2000). Strategizing through the organization: Managing conflict in strategic renewal. Academy of Management review, 25(1), 154177. Retrieved from https://doi.org/10.5465/amr.2000.2791608

Gallin D. (2001). Preposition on Trade Union and informal employment in times of globalization. Retrieved from https://doi.org/10.1111/1467-8330.00197

Guthrie, J. P. (2001). High involvement work practices, turnover, and productivity. Evidence from New Zealand. Academy of Management Journal 44(1), 180190. Retrieved from https://doi.org/10.5465/3069345

Hafford B. N. and Koops L. (2009). The impact of unionization on negotiated wages in the manufacturing sector in Kenya.Oxford Bulletin of Economics and Statistics, vol. 102, no.3, pp. 111-123. Retrieved from https://doi.org/10.1111/j.1468-0084.1976.mp38002003.x

Hyman, R (2021). Understanding European trade unionism between market, class and society. Sage.

Meardi, G. (2000). Trade union activists, east and west: comparisons in multinational companies. Aldershot/Burlington. Ashgate.

Taylor P. and Bain P. (2001). Trade Unions, workers right and frontier of control in UK call centres. Retrieved from https://doi.org/10.1177/0143831X01221003

Visser, J (2002). 'Why Fewer Workers Join Unions in Europe : A Social custom Explanation of Membership Trends', British Journal of Industrial Relations, Vol.40(3). Retrieved from https://doi.org/10.1111/1467-8543.00241 